\title{
慢性関節リウマチ，シェーグレン症候群に 合併した封入体筋炎の 1 例
}

\author{
丸山俊昭・福田哲也・立石睦人・寉田哲朗

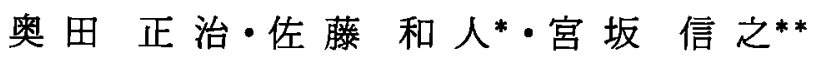

Jpn. J. Clin. Immun., 15 (4) : $397 \sim 404,1992$.

\section{A case of inclusion body myositis}

complicated with rheumatoid arthritis and Sjögren's syndrome

Toshiaki Maruyama, Tetsuya Fukuda, Mutsuto Tateishi, Tetsuro Kubota, Masaharu Okuda, Kazuto Satoh* and Nobuyuki Miyasaka**

The First Department of Internal Medicine, Tokyo Medical and Dental University

*Institute of Rheumatology, Tokyo Women's Medical College

**Division of Immunological Diseases, Medical Research Institute,

Tokyo Medical and Dental University

\section{【Summary】}

A 51-year-old male with rheumatoid arthritis (stage III, class II) was admitted to our hospital because of progressive proximal muscular weakness with atrophy. Laboratory data showed elevated levels of myogenic enzymes including creatine kinase. Electromyogram showed myogenic changes and deltoid muscle biopsy demonstrated muscle atrophy with marked inflammatory cell infiltration showing follicle formation. Further examination revealed a complication of Sjögren's syndrome associated with monoclonal gammopathy. He started to be treated with $40 \mathrm{mg} /$ day of prednisolone (PSL) with remarkable clinical responses. Insidious but progressive muscular weakness with atrophy became evident, however, when PSL was tapered to $10 \mathrm{mg} / \mathrm{day}$. Concomitant use of oral cyclophosphamide was not effective and he was again admitted. Both proximal and distal muscular atrophy was prominent with mild elevation of myogenic enzymes. Light microscopy of muscle biopsy specimens showed degenerative muscle fibers with numerous rimmed vacuoles. Furthermore, electron microscopy disclosed intranuclear and intracytoplasmic inclusions, and a definite diagnosis of inclusion body myositis (IBM) was made. Whether he had IBM 
from the beginning or had polymyoistis in his early course as an initiation of IBM is discussed on the basis of immunohistochemical studies.

\author{
Key words : inclusion body myositis, \\ polymyositis, \\ rheumatoid arthritis, \\ Sjögren's syndrome
}

\title{
【概 要】
}

慢性関節リウマチ，シェーグレン症候群に合併した封入体筋炎の 1 例を報告する. 症例は 53 歳男性. 51 歳 時, 筋力低下にて入院. 近位筋群の筋力低下と筋原性酵素值の上昇, 筋生検にて著明な炎症細胞浸潤を伴う筋原 性変化を認め, 慢性関節リウマチとシェーグレン症候群に合併した多発性筋炎と診断. prednisolone (PSL) 40 $\mathrm{mg}$ /日投与し, 筋力は回復, 筋原性酵素も正常化した。しかし, PSLを $10 \mathrm{mg}$ /日に漸減した頃（10力月後）よ り, CPK の上昇と筋力低下, 筋萎縮の進行を認め, cyclophosphamide $50 \mathrm{mg} /$ 日投与したが改善せず, 2 回目 の入院となった。近位筋群に加え, 遠位筋群にも筋力低下と筋萎縮が明らかで, 再度, 筋生検を施行したとこ ろ, rimmed vacuole が目立ち, 電顕にて filamentous inclusionを認め, 封入体筋炎の確定診断が得られた. 自 己免疫疾患に封入体筋炎が合併したとする報告は少なく，免疫組織学的所見と併せて報告する.

\section{I. 緒 言}

自己免疫疾患は，いくつかの疾患が合併したり，互 いに移行することが知られている。

我々は，病初期には典型的な多発性筋炎（PM）の 筋生検像を示しながら， 3 年後には封入体筋炎 (IBM) と診断された，慢性関節りウマチ（RA）と シェーグレン症候群（SjS）の合併症例を経験した。 IBM と他の自己免疫疾患の合併例の報告は少なく, 臨床的に興味深い症例と考え, その概略に免疫組織的 検討，および若干の文献的考察を加光報告する。

\section{II. 症例}

患 者: 53 歳, 男性, 会社員.

主 訴: 筋力低下.

家族歴およひ既往歴：特記すべきことなし.

現病歴：昭和 50 年頃より眼の乾燥感があった。昭 和 53 年頃, 右膝関節痛にて近医受診しRA を疑わ れ, 疼痛時のみ prednisolone (PSL) $10 \mathrm{mg}$ 内服し 2 年程で疼痛消失したが, 次第に手指の関節変形が生 じてきた. 昭和 58 年頃よりう歯が多発, 口腔内の乾 燥感が出現し, 昭和 62 年 1 月より, 全身倦点感, 肩 から上肢にかけての脱力感が強くみられたが放置して いた． 6 月検診にて赤沈穴進 $(120 \mathrm{~mm} / \mathrm{hr})$ と血清総 蛋白の異常高值を指摘され，8 月中旬より筋力低下進
行したため, 12 月 10 日某院を受診し $\mathrm{PM}$ と SjS を疑 われ, 精查加療のため 12 月 14 日当科第 1 回目の入院 となった。入入院時, 近位筋群の筋力低下, 筋原性酵素 值の上昇 $(C P K 508 \mathrm{U} / l)$, 筋電図上の近位筋群優位 の筋原性変化, 筋生検での筋線維の変形, 破壊と滤胞 形成を伴うリンパ球の著明な浸潤より, PM と診断し た。また，多発性関節炎の所見，手指の変形，X-p 上の骨びらん, 乾燥性角結膜炎の存在, 唾液腺造影で の apple-tree pattern と口唇生検での, 唾液腺の破壊 像と滤胞形成を伴うリンパ球の著明な浸潤，さらに， 血清 IgGの著明な上昇 $(4,700 \mathrm{mg} / \mathrm{d} l)$, 免疫電気泳 動における IgG， $\nsim$ の増加，M蛋白の存在などの所見 により, RA (stage III, class II), SjS, 良性単クロ ーン性高 $\gamma$ グロブリン血性の診断も同時に下された. 以上より昭和 63 年 1 月 7 日より PSL $40 \mathrm{mg} /$ 日の投 与を開始したところ, 筋力の回復とともに, 28 日以 内に筋原性酵素值も正常化した. PSLを $30 \mathrm{mg} /$ 日に 漸減し 2 月 14 日退院. 同年 6 月 14 日には, $10 \mathrm{mg} /$ 日にまで漸減したが，以後徐々に，CPK 值の上昇と 筋力低下・筋萎縮が進行したため, 平成元年 4 月 4 日 より, cyclophosphamide (CPA) $50 \mathrm{mg} /$ 日の併用投 与を開始し，一過性に CPK 值の低下を認めたが, 11 月 22 日には, $\mathrm{CPK} 577 \mathrm{U} / l$ に上昇し, 筋力低下も進 行したため, 12 月 1 日当科第 2 回目の入院となった. 入院時現症：身長 $165 \mathrm{~cm}$, 体重 $59 \mathrm{~kg}$, 体温 
$35.5^{\circ} \mathrm{C}$, 血圧 $158 / 98 \mathrm{mmHg}$, 脈拍 $60 /$ 分 (整). 結膜 に筫血, 黄染なし. 口腔内は乾燥著明で, う歯は多数 あり, 舌乳頭萎縮を認めた. 胸部に異常なし. 腹部 で, 肝を 1 横指触知した. 四肢で両側手指の尺側偏 位, 外反母趾などの変形を認めた。筋萎縮を上腕二頭 筋, 三頭筋, 前腕, 大腿に高度, 三角筋, 肩甲筋に中 等度認めた（図 1 )。近位筋群, 遠位筋群ともに著明 な筋力低下（左右対称性）を認めた。

入院時検查成績: 一般検查所見（表 1 ）では, 赤沈 が, $17 \mathrm{~mm} / \mathrm{hr}$ と軽度穴進し, 白血球分画で st 21 , seg 58 と核の左方移動を認めたが，尿所見に異常を認 めなかった. 血液生化学的検査では LDH が $596 \mathrm{U} /$ $l$, CPK が $499 \mathrm{U} / l$ (MB 10\%, MM 83\%), Aldolase $6.2 \mathrm{U} / l$, myoglobin $111 \mathrm{ng} / \mathrm{m} l$ と上昇していた. 免疫血清学的検査 (表 2 ) では, CRP 陰性, RA テスト $2+, \mathrm{RAHA}$ テストは 160 倍と陽性であった. $\operatorname{IgG}$ は $1,635 \mathrm{mg} / \mathrm{d} l, \operatorname{IgM}$ は $63 \mathrm{mg} / \mathrm{d} l, \operatorname{IgA}$ は 482 $\mathrm{mg} / \mathrm{d} l$ で, 前回入院時存在した $\mathrm{M}$ 蛋白は今回は認め られなかった. 抗核抗体, 抗 DNA 抗体, 抗 ENA 抗 体, 抗 SS-A 抗体, 抗 SS-B 抗体, 抗 Jo-1 抗体, 抗 SRP (signal recognition particle) 抗体はいずれも 陰性であった。

筋電図では, 左上腕二頭筋と三頭筋, 総指伸筋に, low amplitude, short duration potential と, 前腓骨 筋に polyphasic potential を認めた.

筋生検では, 光顕（図 2 ）では筋線維の大小不同, rimmed vacuole が目立ち，核内に diffuse $に$ eosinophilic lesion を認めた. また, 軽度ながら血管周囲性 にリンパ球浸潤像も認められた。電顕（図 3 ）では筋 内に交差する異常な filament の集族像, 並びに多数 の myeloid body を認めた.

生検組織の免疫組織学的検討：入院時に採取した生 検組織を用いて各種単クローン抗体（日科機より供 与) と ABC (Avidin Biotin Complex) 法を用いた 免疫組織染色法を行った. 第 1 回入院時に行われた口 唇小唾液腺組織生検像では, 図 4 に示すごとく, 浸潤 しているリンパ球は滤胞様構造を取っており, 腺組織 の破壊が著明にみられた，濾胞の中心部を占める細胞 は CD 20 陽性の B 細胞であった.これに対して, 周 辺部には CD 2 陽性の T細胞が取り囲むように存在 し, しかもその大多数は CD 4 陽性であった. HLA$\mathrm{DR}$ 抗原の発現は $\mathrm{B}$ 細胞のみならず, 広く $\mathrm{T}$ 細胞や導 管上皮にも認められた.

次に筋生検組織についてみてみると, 第 1 回目入院

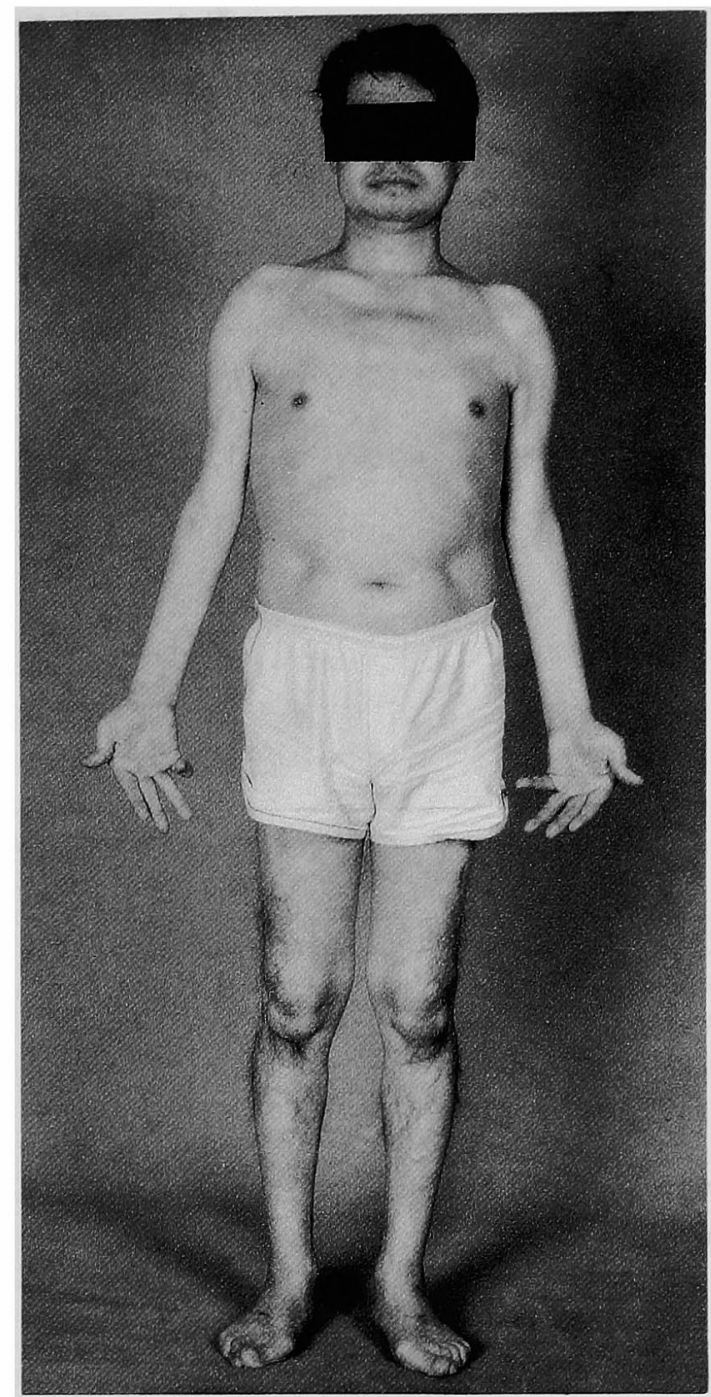

図 1 第 2 回目入院時

RA による手指, 足趾の変形. IBM による筋 萎縮を上腕二頭筋, 三頭筋, 前腕, 三角筋, 大 腿, 肩甲骨に認める。

時には, 筋組織の破壞は著明であり, 筋線維間に著明 な滤胞様のリンパ球浸潤を認めた（図 5 )。浸潤して いる細胞は口唇小唾液腺組織像と同様に, 濾胞の中心 部は $\mathrm{CD} 20$ 陽性の B 細胞であり, その周辺部には $\mathrm{CD} 2$ 陽性の $\mathrm{T}$ 細胞がこれを取り囲むように分布して いた. また大多数の $\mathrm{T}$ 細胞は $\mathrm{CD} 4$ 陽性であり, $\mathrm{CD} 8$ 陽性 T細胞は少数が散在性に存在するにすぎなかっ た. HLA-DR 抗原の発現は，B細胞のみならずT細 胞にも顕著であった.これに対して第 2 回目入院時の 筋生検組織では, リンパ球浸潤の程度は軽微であり, 
表 1 一般検查成績（第 2 回目入院時）

\begin{tabular}{|c|c|c|c|c|}
\hline \multirow[t]{2}{*}{ ESR } & & \multirow[t]{2}{*}{$17 \mathrm{~mm} / \mathrm{hr}$} & \multicolumn{2}{|l|}{ Blood Chemistry } \\
\hline & & & T.P & $7.9 \mathrm{~g} / \mathrm{d} l$ \\
\hline \multirow[t]{7}{*}{$\mathrm{CBC}$} & $\mathrm{RBC}$ & $440 \times 10^{4} / \mu l$ & \multirow{2}{*}{\multicolumn{2}{|c|}{ 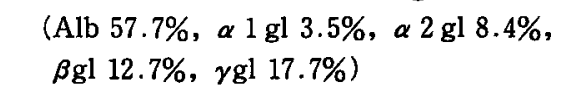 }} \\
\hline & $\mathrm{Hb}$ & $14.8 \mathrm{~g} / \mathrm{d} l$ & & \\
\hline & $\mathrm{Ht}$ & $43.0 \%$ & BUN & $12 \mathrm{mg} / \mathrm{d} l$ \\
\hline & WBC & $5,400 / \mu l$ & $\mathrm{Cr}$ & $0.5 \mathrm{mg} / \mathrm{d} l$ \\
\hline & \multicolumn{2}{|c|}{ (St 21, Seg 58, Baso 1, Ly 14, Mo 6) } & LDH & $596 \mathrm{U} / l$ \\
\hline & \multirow[t]{2}{*}{ Plt } & \multirow[t]{2}{*}{$22.5 \times 10^{4} / \mu l$} & GOT & $47 \mathrm{U} / l$ \\
\hline & & & GPT & $51 \mathrm{U} / l$ \\
\hline \multirow[t]{8}{*}{ Urine } & & $(-)$ & $\mathrm{Al}-\mathrm{P}$ & $149 \mathrm{U} / l$ \\
\hline & G & $(-)$ & $\mathrm{T}-\mathrm{Bil}$ & $0.6 \mathrm{mg} / \mathrm{d} l$ \\
\hline & $\mathrm{K}$ & $(-)$ & $\mathrm{CPK}$ & $499 \mathrm{U} / l$ \\
\hline & OB & $(-)$ & \multicolumn{2}{|c|}{$\begin{array}{l}\text { (BB 1\%, Alb } 2 \%, \text { MB } 10 \% \text {, BAND 14\%, } \\
\text { MM 83\%) }\end{array}$} \\
\hline & & & Aldolase & $6.2 \mathrm{U} / l$ \\
\hline & & & myoglobin & $111 \mathrm{ng} / \mathrm{m} l$ \\
\hline & & & 尿中クレアチニン比 & $52 \%$ \\
\hline & & & 尿中 Bence Jones Protein & $(-)$ \\
\hline
\end{tabular}

表 2 免疫学的㭘査（第 2 回入院時）

\begin{tabular}{lclc}
\hline CRP & $(-)$ & anti SS-A & $(-)$ \\
RA & $2+$ & anti SS-B & $(-)$ \\
RAHA & $1: 160$ & anti Jo-1 & $(-)$ \\
IgG & $1,635 \mathrm{mg} / \mathrm{d} l$ & anti SRP & $(-)$ \\
IgM & $63 \mathrm{mg} / \mathrm{d} l$ & CH 50 & $41.3 \mathrm{U} / \mathrm{m} l$ \\
IgA & $482 \mathrm{mg} / \mathrm{d} l$ & C 3 & $105 \mathrm{mg} / \mathrm{d} l$ \\
ANA & $(-)$ & C 4 & $28 \mathrm{mg} / \mathrm{d} l$ \\
anti ENA & & & \\
RNase sensitive (-) & & \\
RNase resistanj (-) & & \\
\hline
\end{tabular}

滤胞様構造はもはやみられなかった．浸潤しているリ ンパ球の大部分は $\mathrm{CD} 2$ および CD 4 陽性のT細胞で あり，CD 8 陽性 T 細胞はきわめて少数であった。ま た HLA-DR 抗原の発現もきわめて軽度であった。

入院後の経過（図 6)：筋生検で, 筋組織に光顕に $\tau$ rimmed vacuole , 電顕にて filamentous inclusion を認め, 臨床的に近位筋群と遠位筋群の筋力低 下, CPK と Aldolase の上昇を認めたことから, definite IBM と診断された。治療として, PLS 12.5 $\mathrm{mg} /$ 日，CPA $50 \mathrm{mg} /$ 日を続けたところ，12月 14 日 には, CPK $274 \mathrm{U} / l$, Aldolase $4.7 \mathrm{U} / l$ に改善した が, 筋力低下は不変であった。組織に軽度の炎症所見 を認めたことから，ステロイド治療に対する反応を期 待して, methyl PSL $500 \mathrm{mg}$ /日による pulse 療法を 2 クール施行したが, 筋力低下および CPK 值に改善
は認められなかった。

\section{III. 考 察}

本症例は第 1 回目の入院時, 近位筋群の筋力低下, 筋原性酵素值の上昇, 筋電図上の筋原性変化, 筋生検 での炎症性細胞浸潤を伴う筋原性変化より $\mathrm{RA}$ と $\mathrm{SjS}$ に合併した典型的な PM と診断された。しかしそ の後, 徐々に近位筋群および遠位筋群の筋力低下が進 行し，第 2 回目の入院時, 筋生検で電顕にて filamentous inclusion を認められ, IBM と診断された症例で ある。

RA は，第 1 回目入院時，持続する朝のこわばり， 対称性多発性関節炎の所見, 手指変形, $X-p$ 上の骨 びらんの存在, RF 陽性などより 1987 年の ARAの 診断基準の 7 項目中 6 項目を満たす stage III, class IIの RA と診断し, SjS は, シャーマーテスト, 乾燥 性角結膜炎の存在, 唾液腺造影での apple-tree pattern と口唇生検組織像より確認されている.

IBM は, PM, DM ともに idiopathic inflammatory myopathy に分類される特異な疾患である. IBM は, 1967 年にChou が筋炎の患者に細胞質内と核内 に封入体の存在を報告し"，1971 年にYunis と SamahaがIBM として記載したのが最初である2). 現在 までに約 125 例以上の報告があり，本邦でも数例の報 告例がある. Calabreseらの提案した診断基準て は3)，病理的には電顕における microtubular filame- 


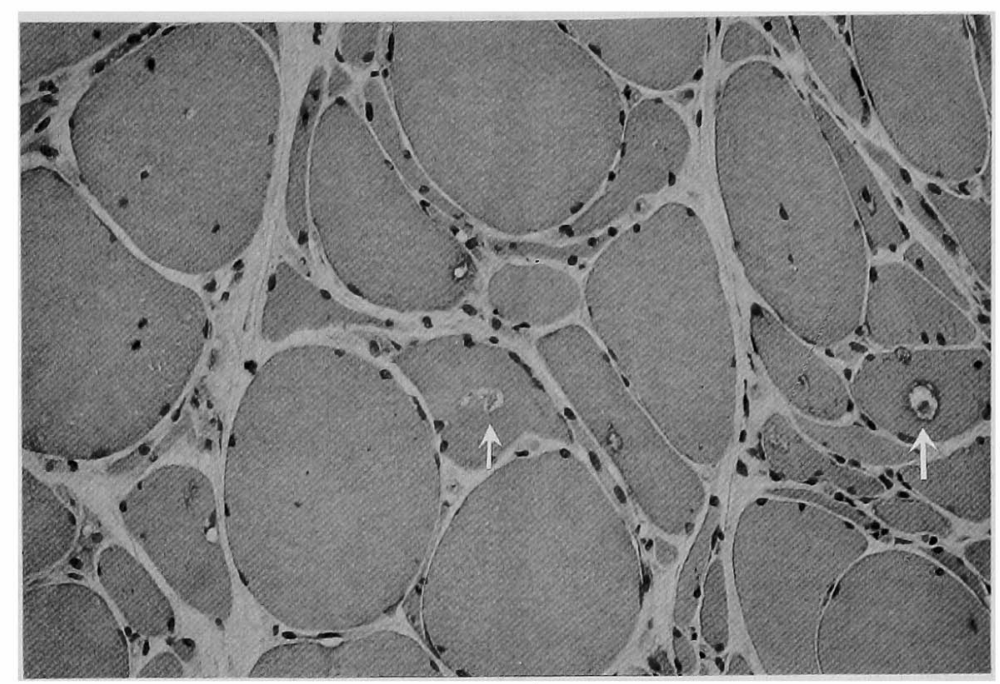

図 2 第 2 回目入院時, 左大腿四頭筋生検組織光顕像 $(\mathrm{HE}, \times 100)$ 筋線維の大小不同と rimmed vacuole を認める ( $\uparrow$ ).

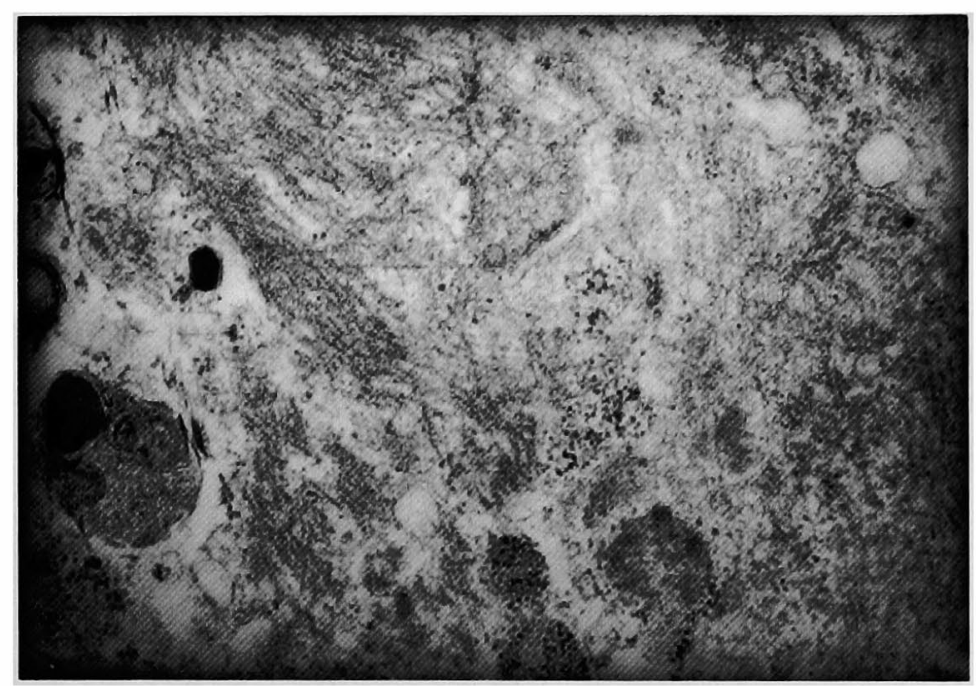

図 3 第 2 回目入院時, 筋生検組織電顕像

交差する異常な filament の集積像, myeloid body を多数認める.

nts in the inclusions, 光顕における 1) rimmed vacuoles, 2) intranuclear and/or intracytoplasmic inclusions, そして, 臨床的には, 1) 近位筋群の筋力低 下，2）遠位筋群の筋力低下，3）筋電図上の全身的な 筋原性変化，4）CPK あるいは Aldolase の上昇，5） ステロイド抵抗性を挙げている。このうち確診例は, 電顕の所見と近位筋群の筋力低下を認め, 臨床所見の

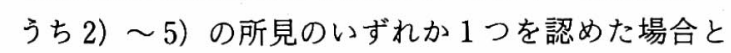
し, 疑診例とは, 光顕の 1) の所見と近位筋群の筋力 低下を認め, 臨床所見の 2）～5）の所見のいずれか
1つを認めた場合としている. 本症例では, 電顕にて 筋組織に filamentous inclusion を認め, 臨床的にも ほほ条件を満たし，確診例と診断された。

IBM と他の自己免疫疾患との合併については, Lotz ら ${ }^{4}$ が報告した 40 例の IBM の中の間質性肺炎, 乾㿏の合併例のほか3 ${ }^{31}$, 皮膚筋炎 ${ }^{51}$, 全身性エリテマ トーデス ${ }^{6)}, \mathrm{SjS}^{7}$ と慢性自己免疫性血小板減少症 ${ }^{8}$ な どの合併の報告がある。しかし，本症例の様に，SjS とRAに合併したIBMの報告例は, 我々が文献上検 索し得た範囲では認められていない. 


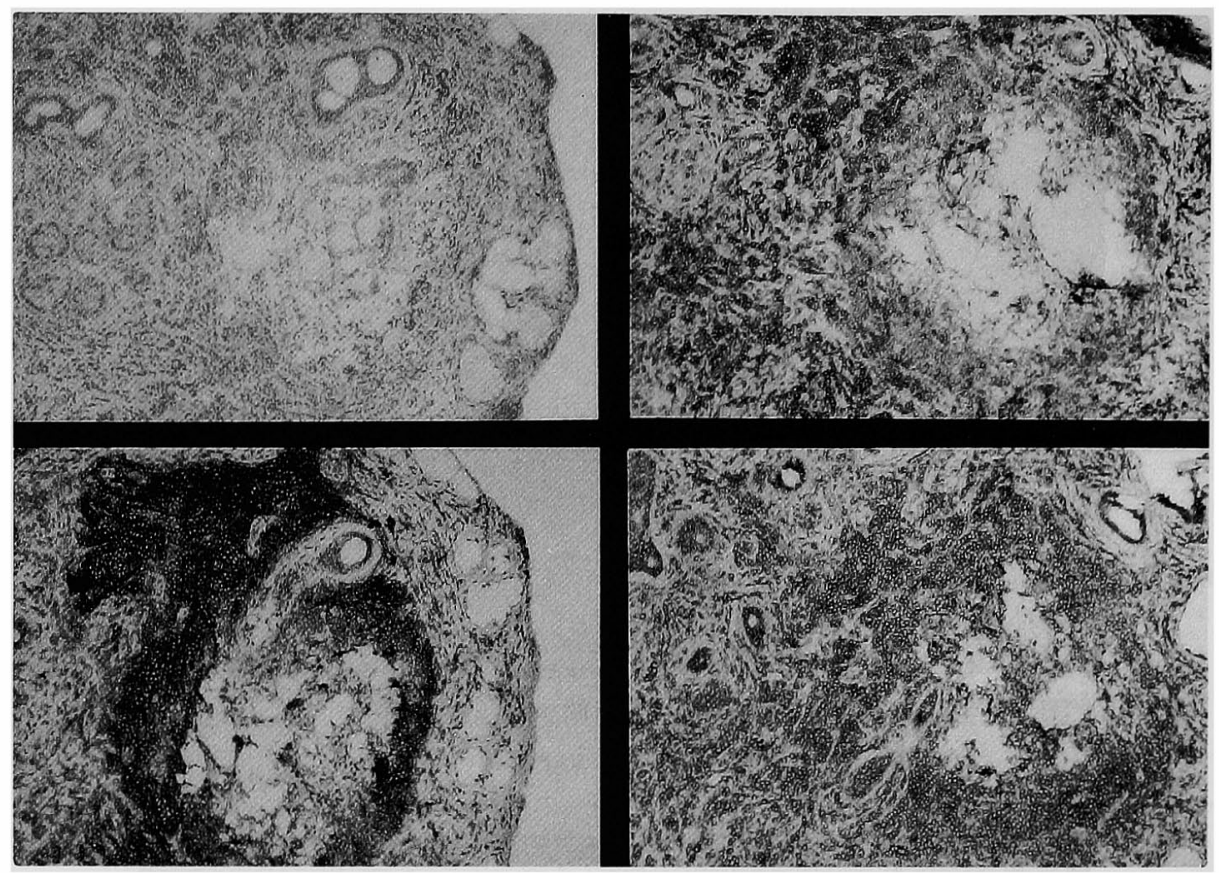

図 4 第 1 回入院時, 口唇小唾液腺生検組織像（連続切片 $\times 40 ）$

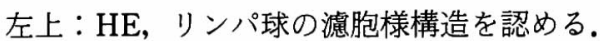

左下：CD 20 陽性（以下 ABC 法）のB細胞が濾胞の中心部を占める.

右上：CD 2 陽性のT細胞が周辺部を取り囲むように存在.

右下：HLA-DR 陽性の細胞はB 細胞，T細胞，そして導管上皮にも認められる.

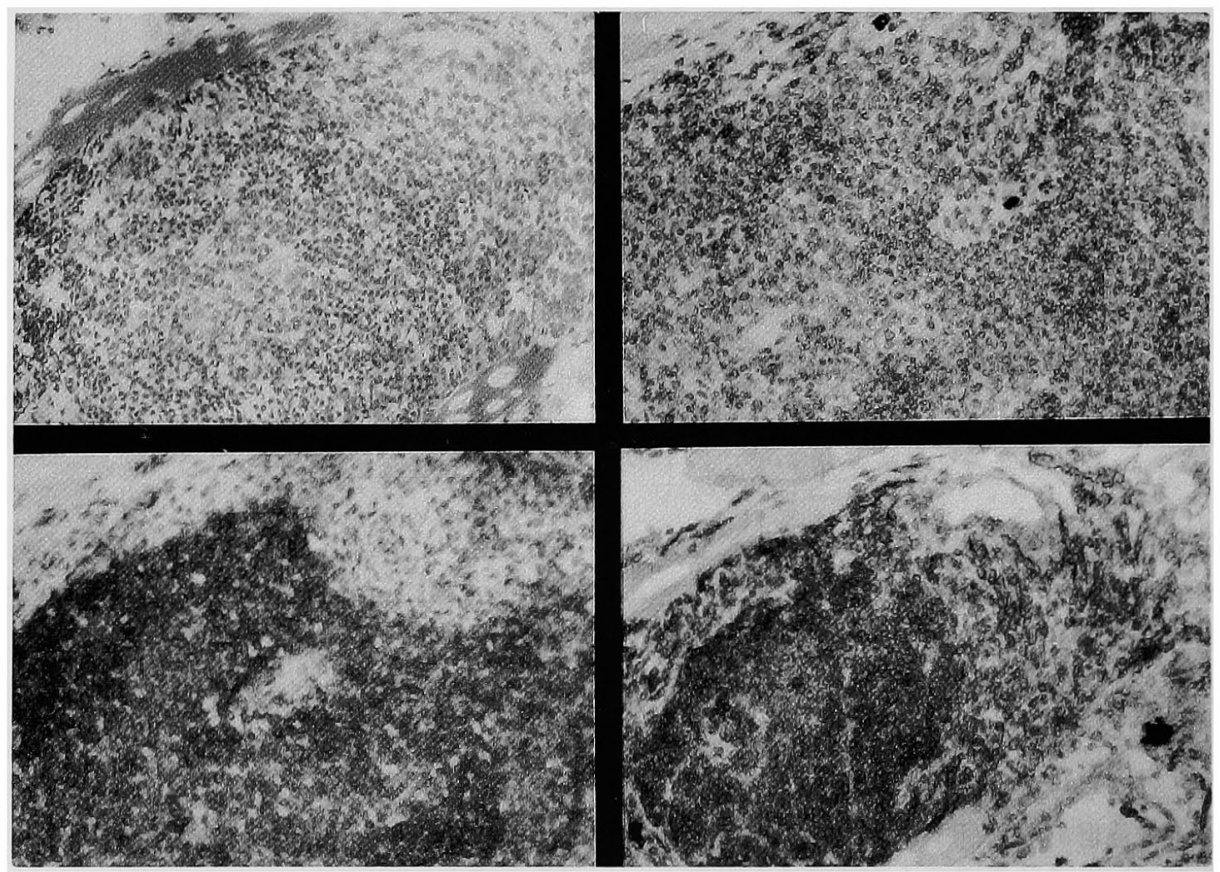

図 5 第 1 回目入院時, 筋生検組織像（連続切片 $\times 100 ）$

左上：HE，口唇小唾液腺と同様リンパ球の滤胞様構造を認める。

左下：CD 20 陽性（以下 ABC 法）の B 細胞が濾胞の中心部を占める。

右上：CD 2 陽性の T細胞が周辺部を取り囲むように存在.

右下：HLA-DR 陽性の細胞は B 細胞，T 細胞ともに認められる。 


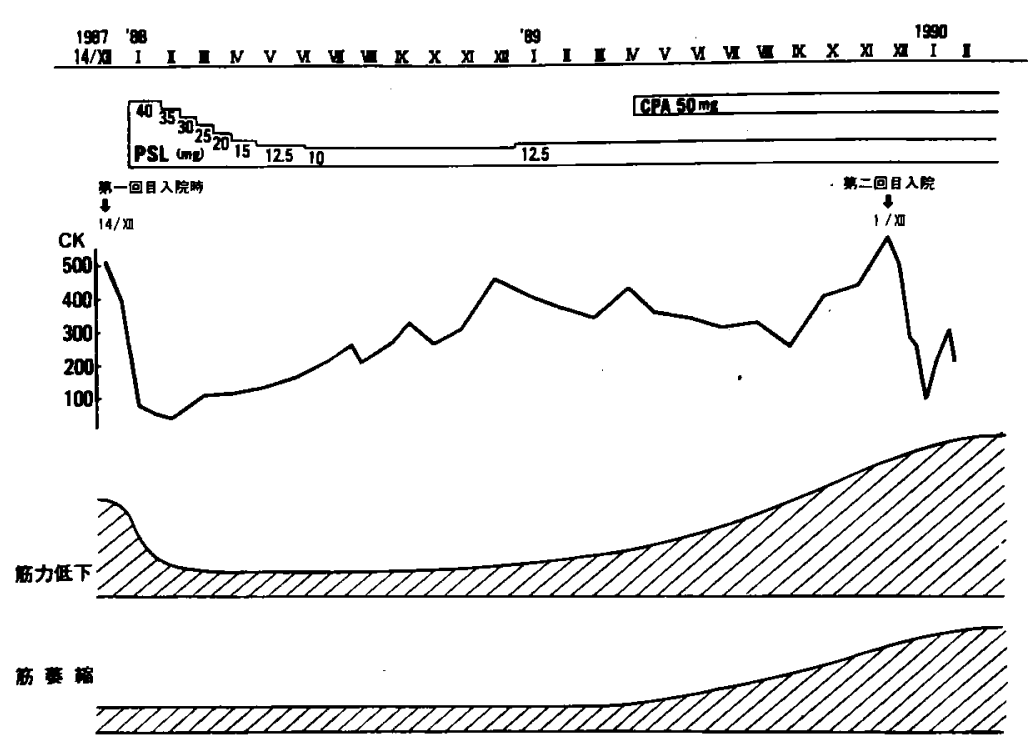

図 6 臨床経過

次に本例が当初より IBMであったのか, あるいは PMからIBMに移行したのかについて論じてみた い. 本例の第 1 回目入院時は, 近位筋に限定された著 明な筋力低下を示し，筋電図上では筋原パターンのみ を認めた。ほか，筋生検組織像では，筋線維の破壞， 変性, 著明なリンパ球浸潤を認め, 定型的な $\mathrm{PM}$ と 診断された。また採取された筋組織中には光顕上, IBM を示唆する rimmed vacuolesや intranuclear/ intracytoplasmic inclusionsなどは確認することはで きなかった。しかし，これらの IBM を示唆する所見 は必ずしも組織内に連続的には存在せず，むしろ病初 期には skip lesion として存在する可能性があること, このときの電顕標本を作成していないこと,などより IBM を否定することはできない，因みに Calabrese ら 3 の報告では, 彼らが経験した 4 例の患者の計 9 回 の筋生榆のうち，8回までにおいて当初は $\mathrm{PM}$ と診 断され，同一の組織を再度，検討しても，なお，うち 2 回においてはPM と組織診断されている。また本 例では, 第 1 回目の入院時も筋力低下が強いわりに $\mathrm{CPK}$ 值があまり上昇していないこと $(504 \mathrm{U} / \mathrm{m} l)$, ステロイド剤に対する反応も当初は良好であったもの の，ステロイド漸隇に伴い筋症状が出現しており，し かも徐々に遠位筋まで侵されたことなどより，むし ろ, 当初より IBM が存在し, 経過とともに典型的な 臨床病像を取った可能性のほうが強く考虑される。

本例では, 臨床経過中, 2 回にわたって筋生検組織 の免疫組織染色を行っている. 第 1 回目は, 滤胞様構
造をとる著明なリンパ球浸潤がみられ，中心部には $\mathrm{CD} 20$ 陽性の $\mathrm{B}$ 細胞が，その周辺部には CD 2 陽性の 丁細胞が存在していた， Т細胞サブセット別にみてみ ると，そのほとんどが CD 4 陽性の，いわゆる helper/inducer タイプであり, CD 8 陽性の suppressor/ cytotoxic タイプは散在性に，かつわずかに認められ るのみであった. HLA-DR 抗原の発現は, B細胞の みならずT細胞上にも広く認められ，活性化 $\mathrm{T}$ 細胞が 多く存在することが推測された。また，第 2 回目の組 織像では, リンパ球浸潤は軽微であり，もはや滤胞構 造は消失していた。また HLA-DR 抗原の発現もきわ めて軽度であった。これはステロイド剤をはじめとす る治療による影響が大と考えられる。しかし，浸潤し ているリンパ球の大部分は依然として CD 2 及び CD 4 陽性であり，この点に扔いては第 1 回目と変化 は認めなかった。PM あるいはIBMの筋組織に関す る免疫組織学的検討は十分にされているとはいえな い. Arahata ら”は，PM と DMでは浸潤リンパ球サ ブセットが異なることを報告している。それによる と，DMの場合には，浸潤リンパ球は主として CD 4 陽性 T細胞と B 細胞であるのに対して, PMでは主と してCD 8陽性 T細胞が主体であるとしている.これ に対して, Rowe ら ${ }^{10} は, P M の$ 筋組織に浸潤するリ ンパ球は CD 4 陽性 Tリンパ球が優位であることを報 告している。また, Foxらは ${ }^{11}, \mathrm{SjS}$ 合併したPM では，唾液腺と筋組織に浸潤するリンパ球はT細胞が 多く，両者とも $\mathrm{CD} 4$ 陽性 $\mathrm{T}$ 細胞が優位であったと報 
告している，一方，IBM に関しては，Arahata ら の報告で, IBM でも PM と同様 CD 8 陽性細胞が主 体であるとしている，以上より，免疫組織学的検討の 結果からは，本例をPM とするか，あるいはIBM と するかについては不明といわざるを得ない，今後，症 例の積み重ねが必要と思われる。

いずれにせよ，本例のように当初，PM と考えられ る症例においても, 治療抵抗性, 難治性の場合, また

文献

1) Chou, S.M. : Myxovirus-like structures in a case of human chronic polymyositis. Sience, $158: 1453 \sim 1455,1967$.

2) Yunis, E.J., Samaha, F.J. : Inclusion body myositis. Lab. Invest., $25: 240 \sim 248,1971$.

3) Calabrese, L.H., Matsumoto, H., Chou, S. M. : Inclusion body myositis presenting as treatment-resistant polymyositis. Arthritis Rheum., $30: 397 \sim 403,1987$.

4) Lotz, B.P., Engel, A.G., Nishino, H. et al. : Inclusion body myositis, observation in 40 patients. Brain, $112:$ 727 747, 1989.

5) Lane, R.J.M., Fulthorpe, J.J., Hudgson, P. : Inclusion body myositis: a case with associated collagen vascular disease responding to treatment. J. Neurol. Neurosurg. Psychiatry, $48: 270 \sim 273,1985$.

6) Yood, R.A., Smith, T.W. : Inclusion body myositis and systemic lupus erythematosus. $\mathrm{J}$. Rheumatol., $12: 568 \sim 570,1985$.

7) Chad, D., Good, P., Adelman, L. et al. : Inclu-
遠位筋が侵されたり，筋電図上，非典型的パターンを 取る場合は，筋生検像を見直し，電影を含めたIBM の検索を行うことが肝要であると考えられる.

謝辞 筋生検組織の電顕によるIBM の診断にご尽 カ下さった神経内科の和田義明先生に感謝の意を表し ます。

sion body myositis associated with Sjögren's syndrome. Arch. Neurol., $39:$ 186 188, 1982.

8) Riggs, J.E., Schochet, S.S., Gutmann, L. et al. : Inclusion body myositis and chronic immune thrombocytopenia. Arch. Neurol., 41 : 93 95, 1984.

9) Arahata, K., Engel, A.G.: Monoclonal antibody analysis of mononuclear cells in myopathies. $\mathrm{V}$ : identification and quantification of $\mathrm{T} 8^{+}$cytotoxic and $\mathrm{T} 8^{+}$suppressor cells. Ann. Neurol., $23: 493 \sim 499,1988$.

10) Rowe, D., Isenberg, D.A., McDougall, J., Beverly, P.C.L. : Charactrization of polymyositis infiltrates using monoclonal antibodies to human leucocyte antigens. Clin. Exp. Immunol., $45: 290 \sim 298,1981$.

11) Fox, R.I., Carstens, S.A. Fong, S. et al. : Use of monoclonal antibodies to analyze peripheral blood and salivary gland lymphocyte subsets in Sjören's syndrome. Arthritis Rheum., $25: 419 \sim 426,1982$. 